\title{
THE INFLUENCE OF METHODICS USED IN SCHOOL LESSONS ON THE LEVEL OF PUPIL'S LOGICAL THINKING
}

\author{
Vlastimil Chytrý ${ }^{1}$, Roman Kroufek ${ }^{2}$, Jan Janovec ${ }^{3}$, Ivana Brtnová-Čerpičková ${ }^{4}$ \\ ${ }^{1}$ Mgr. Ph.D., Jan Evangelista Purkyně University, Czech Republic, vlastimil.chytry@ujep.cz \\ ${ }^{2}$ Mgr., Jan Evangelista Purkyně University, Czech Republic, roman.kroufek@ujep.cz \\ ${ }^{3}$ Mgr. Ph.D., Jan Evangelista Purkyně University, Czech Republic, jan.janovec@ujep.cz \\ ${ }^{4}$ Assoc. Prof. Dr., Jan Evangelista Purkyně University, Czech Republic, ivana.brtnova- \\ cepickova@ujep.cz
}

\begin{abstract}
It is observed that children age period between of 10-12 years which is critical in terms of both dimensional structures and of logical considerations also influences the ability of abstraction which correlates with a pupil's ability to work with the basic logical operators. It is this assumption that leads to the question what logical reasoning in terms of understanding logical connections and general and existential quantifier are pupils of primary school capable of and what impact different approaches or methods in teaching have on this ability. It is necessary to describe the target group in terms of cognitive, verbal and also neurological development in relation to cognitive functions and logical thinking. Also discussed were the issues of the possibility of defining and measuring the logical thinking level, of the effect of gender on the level of logical thinking or of influence of its level on a pupil's assessment in mathematics.

The testing was carried out on 420 respondents attending the fourth and fifth year of primary schools in the Czech Republic. About half of these respondents attend schools that use conventional methods and about half attend schools with other methods.

It is interesting that pupils thought, for example, according to methodologies based on the principles of constructivism reached a higher score in the test focusing on the level of logical thinking than pupils that are taught according to conventional values. However, the survey of statistical significance showed that this difference is not statistically significant. In contrast, the influence of ability to understand basic logical connections on school assessment seems to be significant. The issue of gender influence or other intervening variables on a pupil's ability to work with the basic logical operators is further discussed in the article.
\end{abstract}

Keywords: abstraction, logical thinking, logical connections

\section{INTRODUCTION}

There are three sub-areas reflected in the psychological development of a child whose development and 
mutual interaction cannot be separated. They are bio-social, psycho-social and cognitive development (Vágnerová, 2005). Although cognitive psychology can be considered a separate discipline it is in many ways related to neuroscience, linguistics, anthropology and many other scientific disciplines (Sternberg, 2002). Vágnerová states that the development of thinking among younger pupils is reflected particularly in using strategies of thinking in new ways that respect the basic rules of discovered reality and principles of logic or logical thinking with its significant characteristics, such as decentration, conversation and reversibility. The research described in this article focuses on $7-11$ year-old pupils which is the period that Piaget (1970) called the period of concrete logical operations. At this age, it is the period in which the individual already distinguishes between form and content. Based on that distinction the pupil is able to properly reflect on statements which he or she does not trust (i.e. statements in the form of hypotheses). Such moments can be considered the beginning of the hypothetical-deductive or formal thinking (Piaget, 2010).

The pupil's ability of formal thinking that can be considered a precursor of logical thinking is closely related with one's expressions because the use of language is unique and important manifestation of human thinking. In concordance with its development of the ability to communicate through symbols language and thinking is so strongly intertwined that it is impossible to separate them (Ruisel, 2000). For instance, Carrol (1972) explained in his publication on logical thinking in the example of conversation between two partners. One of parents says: "That's logical" and expresses that his statement derives irretrievably from other, already said and proven statements. So it happens commonly that this statement is not true under the laws of formal logic. Logic is generally understood as a certain process of thinking or the ability to think, or more precisely reason, i.e. to draw conclusions from the given knowledge and ideas.

With the pupil's entrance to first grade of elementary school appears the so-called cognitive revolution which is a change in the way of thinking that is very important for the following development of cognitive process (Steinberg, Belsky, 1991). It is observed that the age 10-12 years which is critical in terms of both dimensional structures and of logical considerations also influences the ability of abstraction which correlates with the pupil's ability to work with the basic logical operators. It is this assumption that leads to the question what logical reasoning in terms of understanding logical connections and general and existential quantifier are pupils of a primary school capable of and what impact different approaches or methods in teaching have on this ability. This issue is further discussed in the following text.

\section{THEORETICAL BASIS OF THE DISCUSSED ISSUE}

The definition of the terms logic, logical thinking and placement of the research into a broader theoretical belong without any doubt among the basic theoretical background of the researched issues which are the basis of logic teaching at elementary schools in the Czech Republic.

\subsection{Characteristics Of The Terms Logic And Logical Thinking}

Logic is considered an independent mathematical discipline that can be defined in two methods. The first is a method based on psychological perspective which describes logic as a scientific discipline exploring train of thought that leads to the right conclusions (Hallet, 1994). The second, mathematical approach, defines logic as a formal science exploring ways of thinking and selection of conclusions from previous premises (Chytrý, Pešout, Ř́čan, 2014). It is obvious that thinking according to laws of formal logic is closely related to the reasoning that Descartes and Bacon divided into two basic forms - deduction ${ }^{1}$ and induction ${ }^{2}$. According to van Wijk (2006) non-equivalence of logical systems and natural language is caused, among other reasons, by the way the brain processes negation. Frege (1992), in contrary, shows that the reason why logic is so difficult to grasp is, in fact, the way it correlates with language that we use on an everyday basis. This issue is discussed in detail by Svoboda and Peregrin (2009). They not only describe the differences in the meaning of phrases in the concept of modern logic from their meaning in everyday speech but also mention complex systems of many-value logics. There is a considerable number of concepts of logical thinking. For the purposes of the research described in this paper the logical thinking will be considered a process where an individual attenuates the content of each piece of information and consistently uses various judgments and their chaining to get a valid conclusion from the initial assumptions.

\subsection{Teaching Logic At Elementary Schools In The Czech Republic}

Starting in 2005, there was an educational reform in the Czech Republic aimed at documents specifying objectives of educational systems. The Framework educational programs (FEP) for individual stages of

\footnotetext{
${ }^{1}$ Deduction is a method to show that one theory emerges from another (Cryan, 2002).

2 Induction is a method used to derive a general rule from several examples (Sternberg, 2002)
} 
education were developed at the state level. This paper is based on the FEP for elementary education in which mathematics is included in educational field Mathematics and its applications. In the aim of the educational area it is explicitly stated: "development of combinatorial and logical thinking, critical judgment and comprehensive and factual argumentation by solving mathematical problems; development of abstract and exact thinking." The results of Czech pupils in mathematics did not develop very favorably in recent years (information based on TIMSS and PISA results 2007). The goal of this paper, however, is not to find a reason for that but to analyze the pupil's ability to work with basic logical connections and to find out to what extent the use of different methodologies affect this ability.

\section{RESEARCH METHODOLOGY}

\subsection{Research Problems, Objectives And Hypotheses}

The research described in this paper focuses on verification of three research problems/questions. The first one is of descriptive and the others of relational character:

- To what extent are pupils of fourth and fifth grades able to work with basic ${ }^{3}$ logical operators?

- How is the pupil's ability to work with logical operators reflected in one's school evaluation?

- What is the difference in logical thinking between students working with textbooks published in the Fraus publication that follow the concept ${ }^{4}$ of professor Hajnýs mathematics and other students?

In order to verify these research problems/questions it was necessary to define the following objectives:

- Design a research tool that verifies the student's ability to work with basic logical operators and is suitable for pupils of the fourth and fifth grade.

- Determine whether the ability to work with logical operators is reflected in school evaluation.

- Determine whether the use of different methodologies affect the pupil's ability to work with logical operators within the laws of formal logic.

There are several hypotheses related to the individual goals or research questions. These hypotheses are not connected to the first research problem as that is descriptive in nature.

$\mathbf{H}_{1}$ : Pupil's school evaluation depends on one's ability to work with logical operators.

$\mathbf{H}_{2}$ : Pupils that are taught according to methodologies based on the constructivist approach are more successful in their work with logical operators then pupils that are taught with other methodologies.

For each of these hypotheses there was always a null hypothesis formulated resulting from the nature of the data and statistical tool.

\subsection{Selection of Respondents/Data Collection}

During the selection of respondents (pupils of fourth and fifth grades), the mental development of the individual that is characterized by the onset of concrete logical operation or abilities to reason according to logical rules was taken into consideration as well as the abstraction phase. This phase lasts from 12 to 30 years of age when abstract thinking is being developed. The target group is in the so-called dimensional structures period or eventually period of logical operations (Vágnerová, 2005).

The total number of respondents is shown in table 1. The first two schools (ZŠ Na Stráni from Děčín and ZŠ Bílá cesta from Teplice) work with conventional methodologies that are based mainly on the transmissive way of teaching. The other two (ZŠ T. G. Masaryka in Česká Kamenice and ZŠ Chomutov) used methodologies based on the constructivist approach of teaching and schema theory. Methodology according to Hejný was chosen as appropriate model based on constructivism which developer as a reaction on the transmissive educational form. Hajnýs methodology became popular in Czech schools during recent years. For the purpose of this paper, the groups working with methodologies based on the constructivist approach are called constructivist methodologies in the tables.

\footnotetext{
${ }^{3}$ The basic logical connections include conjunction, disjunction, negation, implication, and equivalence. Besides these logical connections is the ability to work with general quantifier, and existential quantifier or to solve modified or reversed statement.

${ }^{4}$ This concept is based on the principles of the ten fundamental rules of constructivism and therefore it can be said that these methodologies are designed on the basis of constructivism.
} 


\begin{tabular}{|c|c|c|c|c|c|}
\hline Number of pupils & ZŠ Na Stráni & ZŠ Bílá cesta & ZŠ T. G. Masaryka & ZŠ Chomutov & Total \\
\hline 4th grade & 53 & 48 & 53 & 62 & 216 \\
\hline 5th grade & 40 & 55 & 52 & 57 & 204 \\
\hline Total & 93 & 103 & 105 & 119 & 420 \\
\hline
\end{tabular}

Tab. 1: Number of respondents

\subsection{Design of Research Tool}

If the task is to determine the student's ability to work with the basic logical operators then it is necessary to obtain an evaluation indicator. One option is to alternatively encode individual items $(0-$ student answered incorrectly, 1 - student answered correctly). This method makes it possible to interpret the arithmetic average ${ }^{5}$ of the measured values as an appropriate estimation of $p$ parameter of alternative distribution, i.e. the probability that a randomly selected student answers the question correctly. Therefore, if the value a pupil obtains is 0.56 then this value, in fact, refers to the fact that the pupil manages the items focused on basic pupil logical connections with a probability of $56 \%$. This number will be, for the purposes of this paper, called level of student's logical thinking. The second option to evaluate testing is to evaluate each of the items separately which requires the use of four-field table and Pearson's chi-square test.

The following table (tab. 2) demonstrates the focus of individual test items used in the research. The design of this test is based on the design of standardized tests, such as the test of cognitive abilities, Wechsler Intelligence Test ${ }^{6}$ and Intelligence Structure Test (IST-R).

\begin{tabular}{|c|c|}
\hline Task & Type of researched ability \\
\hline 1 & Ability to work with logical operator - conjunction \\
\hline $\mathbf{2}$ & Abstraction ability in geometry \\
\hline 3 & Ability to work with quantifiers \\
\hline 4 & Ability to work with quantifiers \\
\hline $\mathbf{5}$ & Abstraction ability in geometry \\
\hline $\mathbf{6}$ & Abstraction ability in arithmetic \\
\hline 7 & Ability to work with quantifiers \\
\hline 8 & Negation of complex proposition \\
\hline 9 & Ability to work with logical operator - conjunction \\
\hline 10 & Ability to work with logical operator - disjunction \\
\hline 11 & Ability to work with complex propositions \\
\hline 12 & Ability to work with logical operator - disjunction \\
\hline 13 & Ability to work with "Zebra Puzzle" tasks \\
\hline
\end{tabular}

From this table it is clear that there was also an item focused on the finding of numeric patterns included in the test (item 6) and items aimed at the finding of geometrical patterns (items 2 and items 5). These items were included to examine the impact of abstraction on the pupil's ability to work following the rules of formal logic as one of the crucial factors that can affect the testing. Parameters 2, 4 and 6 will not be further counted with because they don't fit the purpose of the article. These selected parameters have an infinite number of correct answers (correct answers were either intuitive or the respondents were able to explain why their answerer were correct). Students were also asked what final grade they received from the mathematics subject at school last quartile.

\footnotetext{
${ }^{5}$ Only respondents who filled in all questions can be counted in. If a student did not answer one of the questions or if the answers were not complete, the sample had to be discarded.

${ }^{6}$ In order to save capacity in this article the test is not enclosed. The link to the file cannot be added, because the test itself exists only in print.
} 


\section{RESEARCH EVALUATION}

The research evaluation was divided into two parts. The first part is dedicated to descriptive analysis and outline of fundamental differences between experimental groups. In the second part the statistical significance of these differences is verified. Also reflection of the pupil's ability to work with basic logical connections on one's school evaluation is mentioned in the research evaluation.

\subsection{Elementary Descriptive Analysis Of The Measured Values}

It is interesting to observe the differences in the pupil's results not only in the whole test but when individual items are compared. For clarity, the individual outputs of descriptive analysis are presented in the following table (Tab. 3). Presented numbers represent the percentage of correct answers to individual questions.

\begin{tabular}{|c|c|c|c|c|c|c|c|c|c|c|c|c|}
\hline 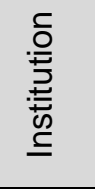 & 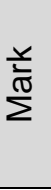 & $\begin{array}{l}\bar{\omega} \\
\stackrel{0}{ \pm} \\
\frac{0}{0} \\
\frac{1}{3} \\
3\end{array}$ & $\begin{array}{c}\bar{x} \\
\frac{\mathfrak{w}}{\sigma} \\
\vdash\end{array}$ & $\begin{array}{l}m \\
\frac{x}{w} \\
\text { ฮ }\end{array}$ & $\begin{array}{l}\nabla \\
\text { v } \\
\text { ठ } \\
\mapsto\end{array}$ & $\begin{array}{l}\text { N } \\
\frac{x}{w} \\
\stackrel{D}{-}\end{array}$ & $\begin{array}{l}\infty \\
\text { w } \\
\text { ठ } \\
\vdash\end{array}$ & $\begin{array}{l}\sigma \\
\text { Ẽ } \\
\stackrel{0}{-}\end{array}$ & $\begin{array}{l}\frac{0}{x} \\
\frac{x}{w} \\
\stackrel{\varpi}{-}\end{array}$ & $\begin{array}{l}\overline{7} \\
\frac{x}{w} \\
\stackrel{0}{\sigma} \\
F\end{array}$ & $\begin{array}{l}\frac{N}{v} \\
\frac{y}{w} \\
\stackrel{\sigma}{-}\end{array}$ & $\begin{array}{l}\frac{m}{x} \\
\frac{x}{w} \\
\stackrel{\sigma}{-}\end{array}$ \\
\hline \multirow{5}{*}{ 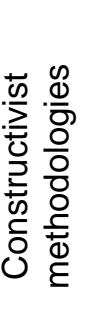 } & $A$ & $70 \%$ & $75 \%$ & $33 \%$ & $39 \%$ & $64 \%$ & $84 \%$ & $88 \%$ & $58 \%$ & $69 \%$ & $71 \%$ & $80 \%$ \\
\hline & $B$ & $56 \%$ & $51 \%$ & $17 \%$ & $19 \%$ & $64 \%$ & $60 \%$ & $83 \%$ & $40 \%$ & $59 \%$ & $56 \%$ & $72 \%$ \\
\hline & C & $42 \%$ & $41 \%$ & $9 \%$ & $9 \%$ & $47 \%$ & $47 \%$ & $76 \%$ & $20 \%$ & $41 \%$ & $21 \%$ & $76 \%$ \\
\hline & D & $34 \%$ & $10 \%$ & $0 \%$ & $0 \%$ & $60 \%$ & $50 \%$ & $70 \%$ & $10 \%$ & $30 \%$ & $10 \%$ & $50 \%$ \\
\hline & $E$ & --- & --- & --- & --- & --- & --- & --- & --- & --- & --- & --- \\
\hline \multirow{5}{*}{ 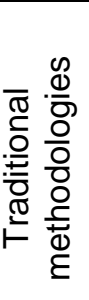 } & $A$ & $70 \%$ & $74 \%$ & $32 \%$ & $44 \%$ & $81 \%$ & $82 \%$ & $88 \%$ & $57 \%$ & $73 \%$ & $71 \%$ & $79 \%$ \\
\hline & $B$ & $66 \%$ & $60 \%$ & $18 \%$ & $45 \%$ & $79 \%$ & $78 \%$ & $91 \%$ & $44 \%$ & $65 \%$ & $59 \%$ & $88 \%$ \\
\hline & C & $44 \%$ & $58 \%$ & $3 \%$ & $10 \%$ & $65 \%$ & $39 \%$ & $84 \%$ & $26 \%$ & $42 \%$ & $29 \%$ & $68 \%$ \\
\hline & D & $40 \%$ & $13 \%$ & $0 \%$ & $13 \%$ & $38 \%$ & $63 \%$ & $63 \%$ & $13 \%$ & $50 \%$ & $13 \%$ & $75 \%$ \\
\hline & $E$ & --- & --- & --- & --- & --- & --- & --- & --- & --- & --- & --- \\
\hline
\end{tabular}

Tab. 3: Percentage of correct answers in relation to school assessment

The fundamental differences that occur between the two groups of respondents should be specified. When only the best pupils from both groups are compared then the differences are barely noticeable. However, when the focus is on the respondents with evaluation between $B$ and $D^{7}$ then some nuances start to appear. It is interesting that some of the items were more suitable for the respondents taught by traditional methodologies and other items than for the respondents taught by methodologies based on constructivism. Explanation and deeper analysis will be done when statistically significant difference is verified. It is the issue of significance that the whole next chapter is focused on. If a similar descriptive analysis was done with the exception that it would not only focus on the testing as a whole but also the basic difference between boys and girls then it would seem like there is barely any difference between them, as can be observed in the following table:

\begin{tabular}{|l|c|c|c|c|c|c|c|c|}
\hline \multirow{2}{*}{$\begin{array}{l}\text { Gender } \\
\text { and age }\end{array}$} & \multicolumn{4}{|c|}{ Traditional methodologies } & \multicolumn{3}{c|}{ Constructivist methodologies } \\
\cline { 2 - 9 } & Mark & Number & Percentage & Median & Mark & Number & Percentage & Median \\
\hline \multirow{3}{*}{$\begin{array}{l}\text { Boys 4th } \\
\text { grade }\end{array}$} & $\mathrm{A}$ & 17 & $59 \%$ & $54 \%$ & $\mathrm{~A}$ & 26 & $59 \%$ & 62 \\
\cline { 2 - 9 } & $\mathrm{B}$ & 12 & $58 \%$ & $54 \%$ & $\mathrm{~B}$ & 13 & $60 \%$ & 62 \\
\cline { 2 - 9 } & $\mathrm{C}$ & 4 & $59 \%$ & $54 \%$ & $\mathrm{C}$ & 6 & $57 \%$ & 62 \\
\cline { 2 - 9 } & $\mathrm{D}$ & ------- & ------ & ------ & $\mathrm{D}$ & ------ & ------ & ----- \\
\hline Girls 4th & $\mathrm{A}$ & 27 & $58 \%$ & $54 \%$ & $\mathrm{~A}$ & 24 & $60 \%$ & 62 \\
\hline
\end{tabular}

${ }^{7}$ There were only a few respondents available for this part of the study and the results given are therefore only an approximate. 


\begin{tabular}{|c|c|c|c|c|c|c|c|c|}
\hline \multirow[t]{3}{*}{ grade } & $B$ & 12 & $58 \%$ & $54 \%$ & $B$ & 21 & $66 \%$ & 62 \\
\hline & C & 3 & $61 \%$ & $62 \%$ & $\mathrm{C}$ & 3 & $51 \%$ & 46 \\
\hline & D & 1 & $46 \%$ & $46 \%$ & $D$ & 1 & $23 \%$ & 23 \\
\hline \multirow{4}{*}{$\begin{array}{l}\text { Boys 5th } \\
\text { grade }\end{array}$} & $A$ & 16 & $59 \%$ & $62 \%$ & $A$ & 14 & $63 \%$ & 62 \\
\hline & $B$ & 16 & $56 \%$ & $54 \%$ & $B$ & 20 & $63 \%$ & 62 \\
\hline & $C$ & 5 & $61 \%$ & $62 \%$ & $\mathrm{C}$ & 8 & $60 \%$ & 62 \\
\hline & D & --------- & --------- & --------- & $D$ & 1 & $54 \%$ & 54 \\
\hline \multirow{4}{*}{$\begin{array}{l}\text { Girls 5th } \\
\text { grade }\end{array}$} & $A$ & 22 & $59 \%$ & $62 \%$ & $A$ & 13 & $65 \%$ & 69 \\
\hline & $B$ & 13 & $58 \%$ & $58 \%$ & $B$ & 24 & $64 \%$ & 69 \\
\hline & C & 7 & $56 \%$ & $54 \%$ & $\mathrm{C}$ & 10 & $59 \%$ & 62 \\
\hline & D & 1 & $38 \%$ & $38 \%$ & D & 6 & $59 \%$ & 62 \\
\hline
\end{tabular}

Tab. 4: Elementary descriptive statistics in dependence on gender

The table shows that there are not significant differences between girls and boys regardless to whether they are at fourth and fifth grade or by what methodology they are being taught. This is attributed to the fact that the logical thinking is closely related to abstraction and as Gardner states (2000), there is a difference of abstraction between men and women only when their IQ is higher than 135 . It is assumed that the respondents of this research do not reach such high IQ values.

\subsection{Research Evaluation}

The evaluation of the research is divided into several parts. The first part is dedicated to the analysis of obtained data and then the focus is on the significance of the differences between the examined groups of respondents. To be able to choose an appropriate statistical method for hypothesis $\mathrm{Hx}$ verification it is necessary to verify the normality of the data. The verification of normality was based on the Shapiro-Wilk test. The $p$-level values are shown in the following table (5). For more detailed examination of the sample, the respondents were further divided according to classes.

\begin{tabular}{|l|c|}
\hline \multicolumn{1}{|c|}{ The researched areas } & $P$-level value \\
\hline 4th grade - pupils taught according to prof. Hejnýs methodology & $p=.0108$ \\
\hline 4th grade - pupils taught according to traditional methodology & $p=.0145$ \\
\hline 5th grade - pupils taught according to prof. Hejny's methodology & $p=.0012$ \\
\hline 5th grade - pupils taught according to traditional methodology & $p=.0091$ \\
\hline
\end{tabular}

Tab. 5: Testing of normality

Because the $p$-level values are less than 0.05 in all the researched areas the null hypothesis of normality data can be rejected for every part. Therefore, the statistical methods corresponding with data of nonparametric character will be used.

\subsubsection{The influence of used methodology on pupil's ability to work with logical operators}

In this part of the article the impact of the used methodology od teaching on the pupil's ability to work with logical operators will be examined. The entire evaluation will be done in two ways. In the first part, the focus is on the overall results of the test (so the individual's ability to abstract will not be taken into consideration). In the second part, the focus is on each of the items individually. Due to the large number of respondents, the evaluation is always divided in two groups of fourth graders and fifth graders. Their overall level of student's logical thinking is demonstrated in the following table:

\begin{tabular}{|l|c|c|}
\hline & Constructivist methodologies & Traditional methodologies \\
\hline 4th grade & $59,92 \%$ & $57,65 \%$ \\
\hline 5thgrade & $64,32 \%$ & $59,36 \%$ \\
\hline
\end{tabular}

Tab. 6: Success of respondents according to the methodologies 
It is obvious that there is not any large difference between the two methodologies. To verify whether the difference is statistically significant, it was necessary to design the following null hypotheses for the abovementioned factual hypothesis. The null hypothesis had to then be verified with the appropriate statistical methods.

Note: If we will compare two methodologies from the perspective of students ability to successfully fill the numbers into a set, we can observe several significant differences, as shown in the following table:

\begin{tabular}{|c|c|c|}
\hline & Constructivist methodologies & Traditional methodologies \\
\hline 4th grade & $38,26 \%$ & $50,45 \%$ \\
\hline 5thgrade & $52,29 \%$ & $34,73 \%$ \\
\hline
\end{tabular}

Tab. 7: Comparison of both methodologies in relation to student's ability to fill the set of numbers

$\mathbf{H}_{1 \mathrm{a}-0}$ : Medians of the values, corresponding with the level of fourth graders' and fifth graders' logical thinking that are taught according to constructivist methodologies and according to traditional values, are equal.

Due to the fact that the data is of nonparametric character and of metric type, the Mann-Whitney test will be used for their comparison. The determined $p$-level values were $p=.342$ for fourth graders and $p=.383$ for fifth graders. Based on the $p$-level values it is possible to conclude that the differences in understanding of basic logical connections between pupils taught by traditional methods and pupils taught by constructivist methods are not significant.

The next section of the paper focuses on analysis of individual items. In the following table the p-level values for Pearson's chi-square test for four-field and contingency table are shown to verify the null hypothesis $\mathrm{H}_{1 \mathrm{~b}-0}$.

$\mathbf{H}_{1 \mathrm{~b}-0}$ : Medians of values, corresponding with individual items aimed at the ability to correctly work with basic logical operators among pupils of fourth and fifth grades that are taught according to constructivist methodologies and pupils that are taught according to traditional methodologies are equal.

\begin{tabular}{|c|c|l|l|}
\hline Item number & Type of researched ability & 4th grade & 5th grade \\
\hline 1 & Ability to work with logical operator - conjunction & $p=.69$ & $p=.46$ \\
\hline 3 & Ability to work with quantifiers & $p=.89$ & $p=.13$ \\
\hline 4 & Ability to work with quantifiers & $p=.33$ & $p=.61$ \\
\hline 7 & Ability to work with quantifiers & $p=.24$ & $p=.07$ \\
\hline 8 & Negation of complex proposition & $p=.74$ & $p=.14$ \\
\hline 9 & Ability to work with logical operator - conjunction & $p=.62$ & $p=.50$ \\
\hline 10 & Ability to work with logical operator - disjunction & $p=.40$ & $p=.04$ \\
\hline 11 & Ability to work with logical operator - conjunction & $p=.55$ & $p=.009$ \\
\hline 12 & Ability to work with logical operator - disjunction & $p=.56$ & $p=.85$ \\
\hline 13 & Ability to work with "Zebra Puzzle" tasks & $p=.69$ & $p=.58$ \\
\hline
\end{tabular}

Tab. 8: Evaluation of the difference among individual items

Statistically significant differences between the respondents with different didactic materials can be observed only in items aimed at the ability to work with logical operator disjunction and with logical operator conjunction. The problem is that when the respondents work with logical operators disjunction and conjunction this difference does not occur every time (see item 1,9 or 12).

\subsubsection{Reflection of pupil's logical thinking in his or her school evaluation}

This section relates to hypothesis $\mathbf{H}_{2}$ : Pupil's Marks is dependent on his or her ability to work with logical operators. Due to the fact that the data of logical thinking are of the nonparametric character (metric type) and school evaluation data are of ordinal type, Kruskal-Wallis test was used and the following null hypothesis was established:

$\mathbf{H}_{2-0:}$ Median values of logical thinking among pupils of fourth and fith grade in different evaluation levels are equal. 
This hypothesis was also examined separately for pupils of fourth and fifth grades working with both abovementioned methodologies. P-level values are in the following table:

\begin{tabular}{|l|c|}
\hline \multicolumn{1}{|c|}{ The researched areas } & $P$-level values \\
\hline 4th grade - pupils taught according to prof. Hejný's methodology & $p=.0023$ \\
\hline 4th grade - pupils taught according to traditional methodology & $p=.0006$ \\
\hline 5th grade - pupils taught according to prof. Hejnýs methodology & $p=.0000$ \\
\hline 5th grade - pupils taught according to traditional methodology & $p=.0000$ \\
\hline
\end{tabular}

Tab. 9: $P$-level values in Kruskal-Wallis test

Based on the obtained $p$-level values it is possible to reject the null hypothesis in all areas surveyed at the one percent significance level. The hypothesis $\mathbf{H}_{2}$ can be, therefore, confirmed and it is possible to conclude that the level of logical thinking of the pupil is reflected in his or her school evaluation regardless of the used methodology.

\section{CONCLUSION}

The issue of logical thinking is already quite well mapped and described. For instance, Kaslová (2010) focused on the transition from reasoning to judgement in her five-year study at kindergartens. Her study was based on stimulation of children playing various types of games used to stimulate logical thinking. However, it is not possible to find a publication aimed at comparing the pupils' ability to work with basic logical operators with regard to the methodologies by which they are taught. The research showed that there is a significant difference between the two groups of respondents only when each of the items was examined individually. This difference occurs only among the items focused on the ability to work with logical operators, more specifically conjunction and disjunction. If the difference was found among all the items focused on logical connections it would be possible to conclude that a pupil is mainly influenced by the used methodologies in the given area. Given the fact, however, that this difference was only exceptional, it is not possible to state that the use of methodologies has an impact on a pupil's ability to work with the basic logical operators. It is very clear that the research result can be influenced by a number of other factors, from respondent's gender to teacher's approach. For this reason, there will be a continuation in the research on this issue.

Another area of interest was to determine whether a pupil's ability to work with basic logical operators is reflected in one's school evaluation. In the overall assessment based on percentage of all items of the test and subsequent statistical evaluation, this hypothesis was confirmed for both grades and in both examined methodologies. Thus, it is possible to conclude that a pupil's ability to work with basic logical operators is reflected in his or her school evaluation. The question then is why so few hours are devoted to the issue of logical connections.

It is obvious that based on this research the quality of the examined methodologies and their direct effect on the cognitive abilities of an individual cannot be evaluated in general. It would be, for example, very interesting to evaluate the two methodologies from a didactic point of view, for instance, based on Prưcha's method (Průcha, 1998). Surely it would be useful to observe what results pupils that are taught according to constructivist methods achieve in mathematics and logical thinking in following grades. An important determinant could also be the interest and enthusiasm for mathematics lesson. This was a very pleasant surprise during the visits in schools where pupils are taught according to methods of prof. Hejný and research recording this fact could be a possible alternative option for further research that this field offers.

\section{ACKNOWLEDGMENT}

This paper was supported by the student grant project SGS - CHYTRÝ - Analýza úrovně logického myšlení. No: 43213 - 15000101

\section{REFERENCE LIST}

CARROLL, Lewis. Logika hrou. 1. vyd. Praha: Pressfoto, 1972.

CRYAN, Dan; SHATIL, Sharron. Logika. 1. vyd. Praha: Portál, 2002. 180 s.: il. ISBN 80-7178-707-8.

FREGE, Gottlob. O smyslu a významu. Scientia et Philosophia. 1992, roč. 4, s. 33 - 75.

GARDNER, Howard. Dimenze myšlení. 1. vyd. Praha: Portál, 1999, 398 s. ISBN 80-717-8279-3. 
HALLET, 1994, cit. In CHYTRÝ, Vlastimil, Ondřej PEŠOUT a Jaroslav ŘíčAN. Preference metakognitivních strategií na pozadí úkolových situací $v$ matematice u žákủ druhého stupně ZŠ. Ústí nad Labem: Universita J.E. Purkyně, 2014, 145 s

CHYTRÝ, Vlastimil, Ondřej PEŠOUT a Jaroslav ŘíČAN. Preference metakognitivních strategií na pozadí úkolových situaci v matematice $u$ žáků druhého stupně ZŠ. Ústí nad Labem: Universita J.E. Purkyně, 2014, 145 s.

KASLOVÁ, Michaela. Předmatematické činnosti v předškolním vzdělávání. Praha: Raabe, c2010, 206 s. ISBN 9788086307961.

Maarten van WIJK: Logical connectives in natural language. Leiden, 2006. Dostupné také z: https://www.era.lib.ed.ac.uk/bitstream/handle/1842/5822/VanWijk2006.pdf Dizertační práce (Doctoraalscriptie Algemene Taalwetenschap). Universiteit Leiden Faculteit der Letteren.

JEAN PIAGET, Bärbel Inhelderová. Psychologie dítěte. Vyd. 5. Praha: Portál, 2010.

PIAGET, Jean. Psychologie inteligence. 5. vyd. Praha: Státní pedagogické nakl., 1970.

PRŮCHA, J. Učebnice: teorie a analýzy edukačního média: příručka pro studenty, učitele, autory učebnic a výzkumné pracovníky. Brno: Paido, 1998, 148 s. literatury. ISBN 80-85931-49-4

STERNBERG, Robert J. Kognitivní psychologie. Vyd. 1. Praha: Portál, 2002.

STEINBERG, BELSKY, 1991, cit. In: VÁGNEROVÁ, M. Vývojová psychologie I. Praha: Karolinum, 2005.

SVOBODA, Vladimír a Jaroslav PEREGRIN. Od jazyka k logice: filozofický úvod do moderní logiky. Vyd. 1. Praha: Academia, 2009, 428 s. Galileo, sv. 28. ISBN 978-802-0017-406.

RUISEL, Imrich. Základy psychologie inteligence. 1. vyd. Praha: Portál, 2000, s. 69.

VÁGNEROVÁ, M. Vývojová psychologie I. Praha: Karolinum, 2005. 